Article

\title{
Family Functioning, Self-Concept and Cybervictimization: An Analysis Based on Gender
}

\author{
Ana Romero-Abrio ${ }^{1, *}$, Celeste León-Moreno ${ }^{1}{ }^{(\mathbb{D}}$, Daniel Musitu-Ferrer ${ }^{1}$ and \\ María Elena Villarreal-González ${ }^{2}$ \\ 1 Department of Education and Social Psychology, Pablo Olavide University, 41013 Seville, Spain; \\ cmleomor@upo.es (C.L.-M.); dmusfer@alu.upo.es (D.M.-F.) \\ 2 Faculty of Psychology, Autonomus University of Nuevo Leon, Monterrey 64460, Nuevo Leon, Mexico; \\ maria.villarrealgl@uanl.edu.mx \\ * Correspondence: aromabr@upo.es; Tel.: +34-954-977-959
}

Received: 23 December 2018; Accepted: 18 February 2019; Published: 21 February 2019

\begin{abstract}
The aim of this study was to analyze the relationships between cybervictimization, family functioning, and self-concept in adolescents, while taking the gender perspective into account. A study was conducted with a sample of 8115 adolescents, aged between 11 and 16 years $(M=13.34$; $S D=1.04)$ from the State of Nuevo Leon, Mexico. A MANOVA $3 \times 2$ was performed to analyze the data. The results showed that family functioning, family self-concept, and academic self-concept were higher when cybervictimization was low. It was also observed that, in situations of cybervictimization, the girls had lower family self-concept, lower academic self-concept, and lower family functioning than the boys. The results that were obtained and their implications are discussed in the final section.
\end{abstract}

Keywords: cyberbullying; cybervictimization; family functioning; self-concept; adolescence

\section{Introduction}

In recent decades, advances in Information and Communication Technologies (ICT) have very rapidly changed the way people interact and communicate with each other. For adolescents, smartphones-mobile phones with Internet access-virtual social media, and instant messaging, are part of their daily lives and they provide them with a connected environment for development and socialization (Livingstone et al. 2011; Wachs et al. 2016). However, this incursion of ICT in the day-to-day lives of adolescents also has many negative effects, such as, for example, Internet addiction and behaviors that are associated with cyberbullying (Aricak and Ozbay 2016; Martínez-Ferrer et al. 2018). Recent studies have revealed the alarming increase in cyberbullying in all developed countries, which has raised great concern in social and educational spheres (De Santisteban and Gámez-Guadix 2017; Garaigordobil 2017; Kowalski et al. 2014; Ortega-Barón et al. 2016).

Cyberbullying is defined as any behavior performed by individuals or groups through electronic or digital means, which involves repeatedly sending hostile or aggressive messages with the intention of causing harm or discomfort to others (Tokunaga 2010; Wachs et al. 2016). Despite the similarities between bullying and cyberbullying, such as intentionality, persistence, and imbalance of power (Buelga et al. 2016), cyberbullying has some very particular characteristics that do not occur in bullying, such as the following: the anonymity of the aggressor; the scope and amplitude of spectators; the impossibility of fleeing from aggression in cyberspace; and, the indefinite reproduction of cyber aggression by observers (Aricak and Ozbay 2016; Buelga et al. 2010). Moreover, one specific characteristic of cyberbullying is the higher prevalence of aggressive cybervictims, since the Internet provides victims with tools to defend themselves and counterattack, displaying behaviors that 
they would not dare to express in face-to-face bullying situations (Antoniadou and Kokkinos 2015; Buelga et al. 2017).

In recent years, there has been a notable increase in the amount of research that is focused on the behavior of cyber-aggressors (Giménez Gualdo et al. 2015; Hosseinmardi et al. 2015; Watts et al. 2017). Moreover, numerous authors have analyzed the profile of cyber-victims and their relationship with psychosocial adjustment variables (Ak et al. 2015; Buelga et al. 2017; Stoll and Block 2015).

As regards the effects of cybervictimization on the psychosocial adjustment of adolescents, previous studies have made reference to different socialization scenarios. Thus, at the community level, the relationship between integration variables and community participation and victimization has been analyzed (Martínez Ferrer et al. 2011). In terms of the school context, recent review studies have highlighted the relationship between cybervictimization and learning difficulties (Garaigordobil 2017) and problems of low academic performance (Tokunaga 2010). In the same line, a meta-analysis that as carried out by Kowalski et al. (2014) reported that the adolescents who suffer cybervictimization have a negative perception of the school and little confidence in teachers. Additionally, a study by Ortega-Barón et al. (2016) has analyzed the relationship between cybervictimization and a negative perception of peer relationships.

Previous studies have highlighted that positive family communication favors the self-concept of adolescents within the family, representing a protective factor against cybervictimization, as occurs with family support and parental affection. In contrast, previous studies have highlighted the relationship between family functioning and cybervictimization (Brighi et al. 2012; Sasson et al. 2015). In this respect, some of the authors have reported that deterioration in family functioning contributes to greater victim vulnerability and the longer duration of cyberbullying due, in part, to the lack of family support to deal with problems (Buelga et al. 2016; Navarro et al. 2015).

In relation to personal and behavioral characteristics, in a review paper by Chan and Wong (2015), it has been observed that adolescents who are cybervictimized also suffer problems of low self-control. Additionally, in other studies, cybervictimization has been related to depression (Calvete et al. 2016), anxiety (Litwiller and Brausch 2013), problems of anger and hostility (Aymerich et al. 2018), loneliness and low empathy (Brewer and Kerslake 2015), and suicidal ideation and low self-concept (Brewer and Kerslake 2015; Extremera et al. 2018). As regards self-concept, defined as the perception that individuals have of themselves as physical, social, and spiritual beings (García and Musitu 1999), the authors of this study believe that attention should be drawn to the important role that it plays in the development of adolescent identity. This study was performed using the hierarchical and multidimensional self-concept model (Shavelson et al. 1976) in order to obtain a more sensitive, adjusted, and specific analysis of the measurements (Fuentes et al. 2011). Previous studies have reported that adolescents with high self-concept have higher levels of psychosocial adjustment, such as greater satisfaction with life and less loneliness (Moreno et al. 2009) and lower levels of depression and anxiety than adolescents with low self-concept (Garaigordobil and Durá 2006). In contrast, other authors have associated low self-concept with victimization (Kowalski and Limber 2013) and cybervictimization (Brewer and Kerslake 2015; Extremera et al. 2018; Wachs et al. 2016).

Lastly, regarding the prevalence of cybervictimization according to gender, there is still no consensus among researchers. Certain previous studies have reported that cybervictimization may be more frequent in boys (Durán-Segura and Martínez-Pecino 2015), or no gender differences have been observed (Katzer et al. 2009). Additionally, a meta-analysis by Kowalski et al. (2014) indicated an increased frequency of cybervictimization in girls. In relation to self-concept, in a meta-analysis that was carried out with 32,486 individuals through 115 studies, no gender differences were observed in the familiar and academic dimensions of self-concept (Gentile et al. 2009).

\section{The Current Study}

In the family environment, studies have been carried out on cybervictimization from the perspective of family communication (Buelga et al. 2017), parenting styles (Chou et al. 2016; 
Fuentes et al. 2015), and family atmosphere (Moral Jiménez and Bernal 2013), as well as from the intercultural standpoint (Estévez et al. 2016). However, very few studies have analyzed cybervictimization from the point of view of family functioning (Buelga et al. 2016). There is also extensive literature regarding the relationship between self-concept and cybervictimization, but from the multidimensional perspective of self-concept (Brewer and Kerslake 2015; Buelga and Musitu 2006). In this study, a two-dimensional perspective was chosen, which focused exclusively on the two potentially most significant contexts in the adolescent's life, namely family and school. Thus, consideration was given to the dimensions of family and academic self-concept dimensions, which previous studies have related to low levels of aggressive behavior in school, high academic performance, and better school achievement (Estévez et al. 2006), as well as with other adjustment factors in adolescents, such as substance use (Musitu et al. 2007) and criminal behavior (Cava et al. 2008). In particular, some of the authors have related the family self-concept with high levels of family socialization (Fuentes et al. 2011). In terms of gender, as mentioned previously, no conclusive results have been reached in previous studies regarding the differences between boys and girls in cybervictimization in relation to those variables, namely self-concept and family functioning.

Against this background, the general objective of this study is to analyze the relationship between family functioning, family self-concept, academic self-concept, and cybervictimization in school-aged adolescents based on gender. The expected outcomes are as follows:

Hypothesis 1 (H1). Family functioning would be greater the lower the cybervictimization.

Hypothesis 2 (H2). Academic and family self-concept would be higher in adolescents with low cybervictimization.

Hypothesis 3 (H3). In situations of high cybervictimization, girls would display lower family functioning, lower academic self-concept and lower family self-concept than boys.

\section{Method}

\subsection{Participants}

Proportional stratified sampling was carried out according to urban and rural educational centers (universe of 984 centers), in the State of Nuevo Leon (Mexico) (confidence level 90\%, alpha 0.05). 8,115 adolescents participated (51.5\% boys and $48.5 \%$ girls) from 118 centers (62 urban and 56 rural), of which $62.3 \%$ studied in urban schools and $62.3 \%$ studied in rural schools. Their ages ranged between $11-13$ years old $(54.0 \%)$ and $14-16$ years old $(46.0 \%)$.

\subsection{Instruments}

Family Functioning Scale-APGAR—(Smilkstein et al. 1982). It consisted of five items with three possible answers $(0=$ almost never, $1=$ sometimes, and $2=$ almost always $)$. It evaluates the cohesion and adaptability of family functioning (e.g., "Are you satisfied with the time you and your family spend together?"). Cronbach's alpha was 0.80 . Confirmatory factorial analysis (CFA) using the Maximum Likelihood Model showed good fit of the model to the data $\left[\mathrm{SB} \chi^{2}=40.41, \mathrm{gl}=4, p<0.001\right.$, CFI $=0.996$, RMSEA $=0.033(0.025,0.043)]$.

Self-Concept Form-5 Scale-AF-5-(García and Musitu 1999). This consisted of 30 items, with a response range of $1=$ very little according to $99=$ agree strongly. It measured five dimensions of self-concept: academic self-concept (e.g., "I do schoolwork well"), social self-concept (e.g., "I make friends easily"), emotional self-concept (e.g., "I'm afraid of some things"), family self-concept (e.g., "At home they criticize me a lot"), and physical self-concept (e.g., "I take care of myself physically"). Cronbach's alpha was 0.81 . Its internal consistency for each of its dimensions-academic self-concept and family self-concept-was 0.88 and 0.77 , respectively. The CFA using the Maximum Likelihood model presented an acceptable fit to the data [SB $\chi^{2}=6892.5998, \mathrm{gl}=337, p<0.001$, CFI $=0.958$, RMSEA $=0.050(0.049,0.051)]$. 
Scale of Victimization via Mobile Phone and Internet-CYB-VIC—(Buelga et al. 2012). It consisted of 18 items with four Likert response options (from $1=$ never to $4=$ always). The scale measured the adolescent's experience as a victim of cyberbullying via mobile phone and Internet in the last 12 months. It consisted of two sub-scales: mobile phone victimization (e.g., "I've been insulted or ridiculed with messages or calls"); and, Internet victimization (e.g., "They've gotten into my messenger or private account without being able to do anything"). Cronbach's alpha was 0.89 . The CFA using the Maximum Likelihood Model confirmed the good fit of the model to the data: $\left[\mathrm{SB} \chi^{2}=238.90, \mathrm{df}=124\right.$, $p<0.001, \mathrm{CFI}=0.93, \mathrm{NNFI}=0.91, \mathrm{RMSEA}=0.03(0.024,0.035)]$.

\subsection{Procedure}

The Autonomous University of Nuevo Leon and the Secretariat for Education, of the same state, planned and developed the project. This Secretariat convened the inspectors of the different state regions to inform them of the start of this research and for the latter to, in turn, inform their directors about the interest and relevance of the project in order to grant access to university researchers for the administration of the instruments. PhD students from the Faculty of Psychology $(\mathrm{N}=19)$ received training on all aspects related to the development of the research (administration, attitudes, and behaviour in the process with respect to students and teachers). Once they had been informed and had given their permission, the instruments were administered at the selected centres following the obtainment of permission from the parents and students. For transport purposes, participants living long distances from the centres were provided with a bus service by the Faculty of Psychology. The number of researchers and PhD students who used this service was $\mathrm{N}=25$. In classrooms where there were children with reading and comprehension problems, administration was performed on an individual basis by trained staff. Additionally, all of the students were informed that their participation was voluntary and anonymous and that they could refuse to participate whenever they wished. A total of 19 students $(21 \%)$ refused to participate in the project. The study complied with the ethical values required in research with human beings, respecting the fundamental principles that were included in the Helsinki Declaration (World Medical Association 2013), its amendments and regulations in force (regulating informed consent and right to information, personal data protection and guarantees of confidentiality, non-discrimination, freedom, and the option of abandoning the study in any of its phases).

\subsection{Data Analysis}

First, two cluster analyses were carried out with the two dimensions of cybervictimization that are measured on the scale (mobile phone victimization and Internet victimization), in order to determine the maximum intergroup variability and minimum intragroup variability. Firstly, a two-stage analysis was carried out to obtain the optimal number of groups, followed by a k-means analysis to assign the individuals to each group. The result was that three cybervictimization groups (high, moderate, and low) were obtained, with good fits. The average score was used to determine the prevalence of cybervictimization, resulting in three conglomerates that were compared in accordance with the evaluation of this variable (Closas et al. 2013). Based on the mean, the values were classified, as follows: values between 1 and 1.60 were considered to be low cybervictimization; values between 1.70 and 2.60, moderate cybervictimization; and, values between 2.70 and 5 , high cybervictimization. Subsequently, a multivariate factorial design $($ MANOVA, $3 \times 2$ ) was performed to analyze any interaction effects. The fixed factors were cybervictimization (high, moderate, and low) and gender (boy and girl) and the dependent variables were family functioning and self-concept (family self-concept and academic self-concept). Lost data by scales or sub-scales, provided that they did not exceed $15 \%$, were processed using the multiple linear regression imputation model (Cuesta et al. 2013). Univariate atypical data were detected by the exploration of standardized scores) (Hair et al. 1999). SPSS (edition 25) software was used. 


\section{Results}

\subsection{Descriptive Analysis}

The distribution of adolescents according to gender, cybervictimization, family functioning, and self-concept is shown in Table 1. The percentage of boys and girls, as a function of cybervictimization, was similar in all of the variables.

Table 1. Sociodemographic variables.

\begin{tabular}{|c|c|c|c|c|c|}
\hline \multirow[b]{2}{*}{ Variables } & \multirow[b]{2}{*}{$\begin{array}{l}\text { Total Sample } \\
(\mathrm{N}=8115)\end{array}$} & \multicolumn{3}{|c|}{ Cybervictimization } & \multirow[b]{2}{*}{$x^{2}$} \\
\hline & & $\begin{array}{c}\text { Low } \\
(\mathrm{N}=6525)\end{array}$ & $\begin{array}{l}\text { Moderate } \\
(\mathrm{N}=1328)\end{array}$ & $\begin{array}{c}\text { High } \\
(\mathrm{N}=262)\end{array}$ & \\
\hline Gender & & & & & $28.216^{* * *}$ \\
\hline Boys & 4177 (51.5\%) & 3449 (52.9\%) & $620(46.7 \%)$ & $108(41.2 \%)$ & \\
\hline Girls & 3938 (49.5\%) & 3076 (47.1\%) & 708 (53.3\%) & 154 (58.8\%) & \\
\hline
\end{tabular}

\subsection{Multivariate Analysis}

A MANOVA was performed and statistically significant differences were obtained in the main effects of cybervictimization $\left(\Lambda=0.965, F(6,16,214)=47.89, p<0.001, \eta^{2}=0.017\right)$, and gender $\left(\Lambda=0.995, F(3,8107)=14.85, p<0.001, \eta^{2}=0.005\right)$. A statistically significant interaction effect between cybervictimization and gender was also observed $\left(\Lambda=0.995, F(6,16,214)=6.86, p<0.001, \eta^{2}=0.003\right)$.

As regards cybervictimization, the ANOVA results showed statistically significant differences in family functioning $\left(F(2,1882)=58.859, p<0.001, \eta^{2}=.014\right)$, family self-concept $(F(2,8112)=156.653$, $\left.p<0.001, \eta^{2}=0.037\right)$, and academic self-concept $\left(F(2,8112)=30.281, p<0.001, \eta^{2}=0.007\right)$ (see Table 2$)$. The Bonferroni test $(\alpha=0.05)$ indicated that family functioning, family self-concept and academic self-concept were higher in adolescents with low cybervictimization than in those with high cybervictimization. The effect sizes detected were medium-low, from 0.007 to 0.037 .

Table 2. Means, Standard Deviation (SD) and results ANOVA between cybervictimization and family functionning, family self-concept, and academic self-concept.

\begin{tabular}{cccccc}
\hline \multirow{2}{*}{ Variables } & \multicolumn{3}{c}{ Cybervictimization } & $\boldsymbol{F}$ & $\eta^{\mathbf{2}}$ \\
\cline { 2 - 6 } & Low & Moderate & High & $\boldsymbol{F ( 2 , 8 1 1 2 )}$ \\
\hline FF & $2.484(0.545)^{\mathrm{a}}$ & $2.374(0.545)^{\mathrm{b}}$ & $2.173(0.621)^{\mathrm{c}}$ & $58.859 * * *$ & 0.014 \\
ASC & $81.574(18.558)^{\mathrm{a}}$ & $74.548(21.902)^{\mathrm{b}}$ & $64.636(24.373)^{\mathrm{c}}$ & $156.653 * *$ & 0.037 \\
FSC & $71.339(21.090)^{\mathrm{a}}$ & $67.867(21.802)^{\mathrm{b}}$ & $63.302(22.710)^{\mathrm{c}}$ & $30.281^{* * *}$ & 0.007
\end{tabular}

FF: Family functioning; FSC: Family Self-Concept; ASC: Academic Self-Concept; Bonferroni Test $\alpha=0.05 ; \mathrm{a}>\mathrm{b}>\mathrm{c}$; $* * * * 0.001 ; \eta^{2}=0.01-0.06$ (small effect), $>0.06-0.14$ (medium effect), $>0.14$ (high effect).

In relation to gender, significant differences were obtained in family self-concept $\left(F(1,8113)=18.774, p<0.001, \eta^{2}=0.002\right)$ and in academic self-concept $(F(1,8113)=37.149, p<0.001$, $\left.\eta^{2}=0.005\right)$. As shown in Table 3 , girls showed greater academic self-concept, while boys showed greater family self-concept.

Table 3. Means, Standard Deviation (SD) and results ANOVA between gender and family functioning, family self-concept and academic self-concept.

\begin{tabular}{ccccc}
\hline \multirow{2}{*}{ Variables } & \multicolumn{2}{c}{ Gender } & $\boldsymbol{F}$ & $\eta^{\mathbf{2}}$ \\
\cline { 2 - 5 } & Boy & Girl & $\boldsymbol{F ( 1 , 8 1 1 3 )}$ & \\
\hline FF & $2.468(0.561)$ & $2.444(0.541)$ & 3.797 & 0.000 \\
FSC & $80.797(18.334)$ & $78.901(21.052)$ & $18.774^{* * *}$ & 0.002 \\
ASC & $69.113(20.713)$ & $71.995(21.887)$ & $37.149^{* * *}$ & 0.005 \\
\hline
\end{tabular}

FF: Family functionning; FSC: Family Self-concept; ASC: Academic Self-Concept; ${ }^{* * *} p<0.001 ; \eta^{2}=0.01-0.06$ (small effect), $>0.06-0.14$ (médium effect), $>0.14$ (high effect). 


\subsection{Univariate Analyses of Interaction Effects}

Three interaction effects were obtained. The first interaction was between cybervictimization, gender, and family functioning $\left(F(5,8109)=28.732, p<0.001, \eta^{2}=0.017\right)$. The post-hoc contrast results from the Bonferroni test $(\alpha=0.05)$ indicated that, when cybervictimization was high and moderate, girls perceived worse family functioning, while, when cybervictimization was low, boys and girls similarly perceived high family functioning (Figure 1).

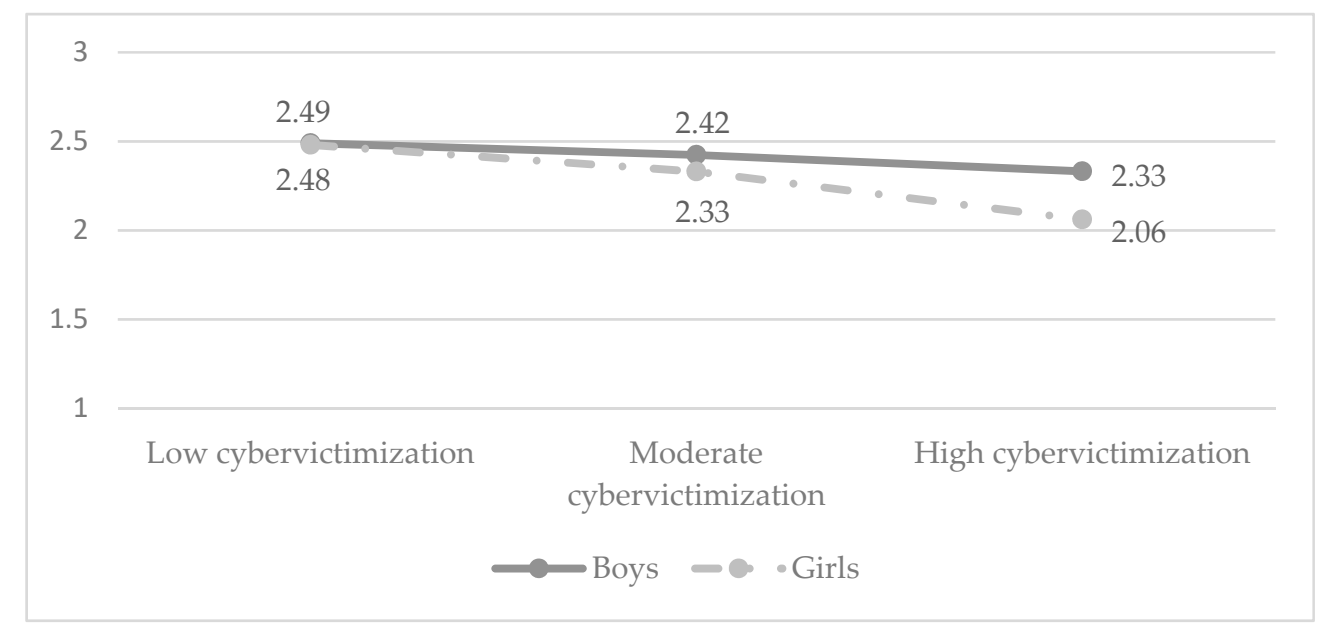

Figure 1. Cybervictimization, family functioning and gender.

The second interaction was between cybervictimization, gender, and family functioning $\left(F(5,8109)=70.654, p<0.001, \eta^{2}=0.042\right)$. Post-hoc contrast results from the Bonferroni test $(\alpha=0.05)$ (Figure 2) indicated that when cybervictimization was moderate and high girls showed lower family self-concept, while, when cybervictimization was low, boys and girls similarly perceived high family functioning.

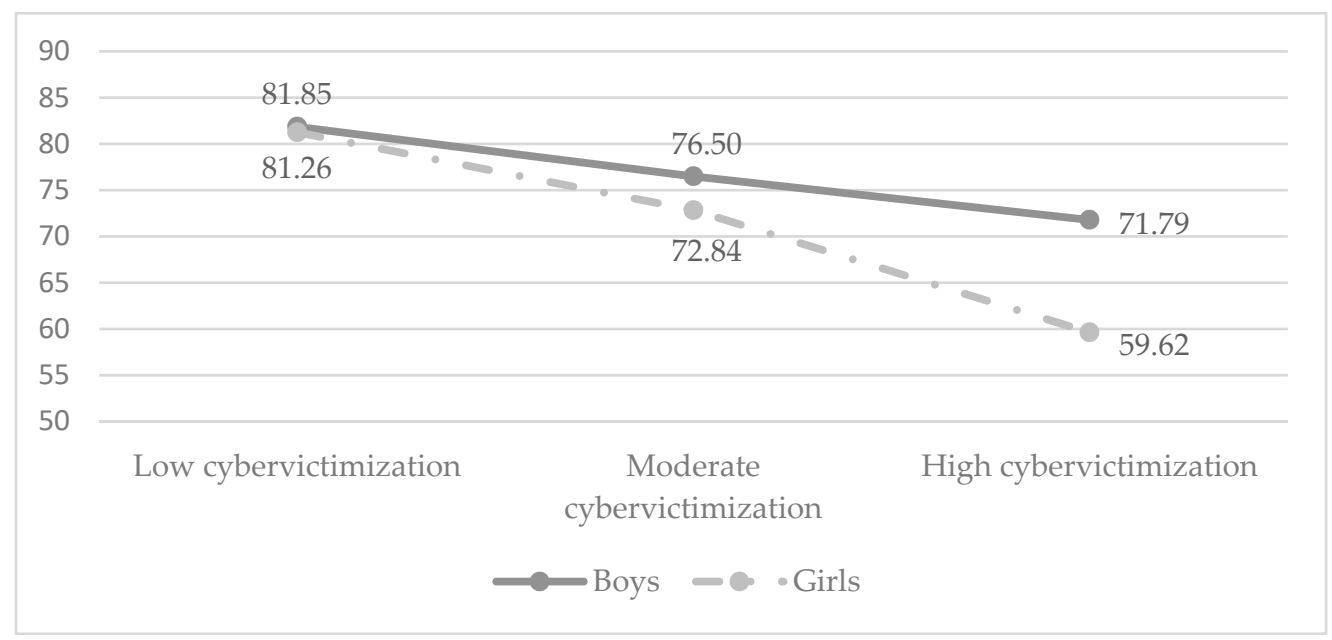

Figure 2. Cybervictimization, family self-concept and gender.

The third interaction was between cybervictimization, gender, and academic self-concept $\left(F(5,8109)=24.889, p<0.001, \eta^{2}=0.015\right)$. As can be seen from the results (Figure 3), when cybervictimization was high, girls showed lower academic self-concept, while, when cybervictimization was low, girls showed higher academic self-concept. Only in the condition of moderate victimization did the boys and girls show similar academic self-concept. 


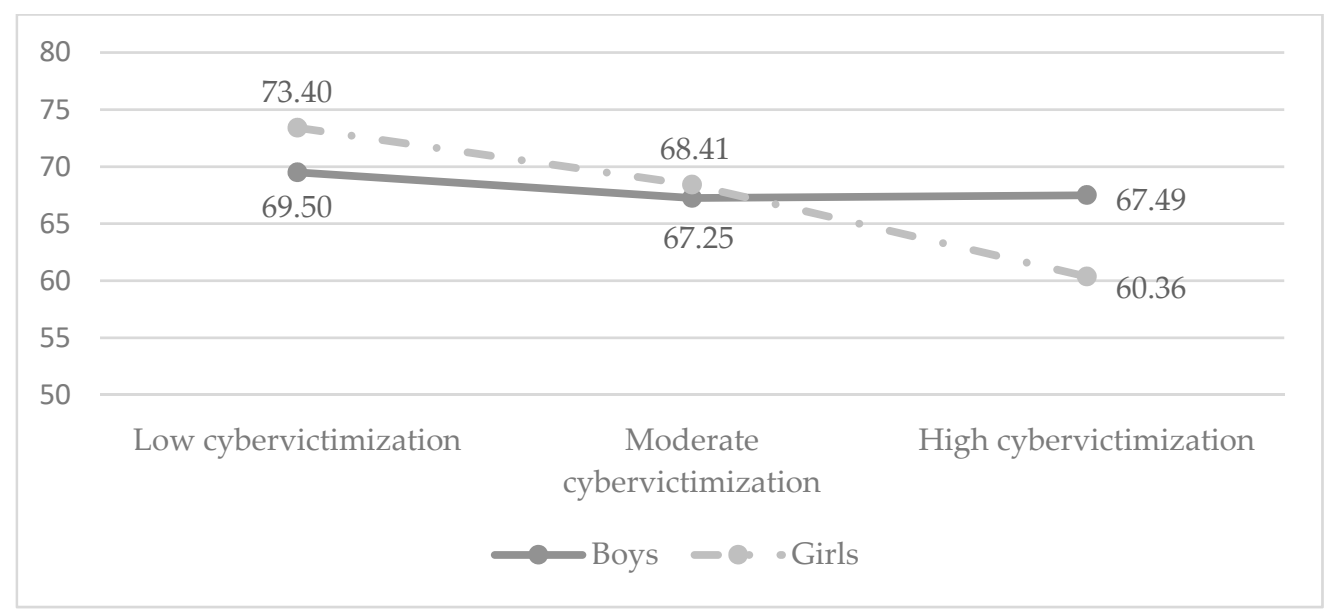

Figure 3. Cybervictimization, academic self-concept, and gender.

\section{Discussion}

This study aimed to analyze the relationships between cybervictimization, family functioning, and academic and family self-concept in school-aged adolescents, while taking into account the gender perspective. The results showed that family functioning, family self-concept, and academic self-concept were significantly related with cybervictimization. Significant differences were observed between boys and girls in these variables in the three conditions of cybervictimization that were analyzed in this study.

As regards family functioning, the results showed that it was the adolescents with low cybervictimization who perceived better family functioning and that higher cybervictimization was associated with lower perception of good family functioning, allowing us to confirm the first hypothesis. These results were consistent with those that were obtained by other authors in the field of family functioning, with variables, such as family communication (Navarro et al. 2015), parenting styles (Fuentes et al. 2015; Huang et al. 2010) and family climate (Ortega-Barón et al. 2016). These findings are also considered to be fundamentally interesting because they provide a new dimension - family functioning - that is considered to bring together the other variables in the family context (Castilla et al. 2014; Martínez-Ferrer et al. 2003; Musitu et al. 2007). Family functioning was also observed to be related with cybervictimization. More specifically, our results show that adolescents with good family functioning are less cyber-victimized than those with poor family functioning. In the same line, previous studies have highlighted that the likelihood of adolescents being cyber-victimized is related to protection variables that are related to family structure and functioning, such as parental affection and family support (Elsaesser et al. 2017; Fanti et al. 2012; Martins et al. 2016).

In relation to self-concept, it was observed that adolescents with low cyber-victimization status reported greater family and academic self-concept, allowing for us to confirm the second hypothesis. These results are consistent with those that were reported in previous studies, which have highlighted that self-concept, together with family functioning, is also a protection factor against cybervictimization (Kowalski et al. 2018). However, this study included the two dimensions of self-concept that are related to family and school, thus enriching the results that were reported previously, insofar as cybervictimization has a reference in both the school and family contexts. Recently, it has also been observed that the relationship between self-concept and cybervictimization may be moderated by positive relationships between parents and adolescent children. More specifically, frequent communication between parents and children is related to high levels of self-concept in adolescents (Özdemir 2014).

As regards gender, and as expected (third hypothesis), the relationships between cybervictimization, family functioning, family self-concept, and academic self-concept differed between boys and girls. Firstly, it was observed that girls with high cybervictimization reported poorer family 
functioning than boys. However, when cybervictimization was low, no gender differences in family functioning were observed. This result is related to the notion that girls are more sensitive to poor family functioning than boys, which could explain more emotional problems and, consequently, reveal greater difficulty in dealing with problems in the family sphere and in other contexts, such as school. These negative experiences linked to emotional resources would explain the victimization (Buelga et al. 2017; Hinduja and Patchin 2012). In this connection, previous studies have reported that girls are better in identifying and expressing emotions than boys in contexts of family violence, such as in cases of child-to-parent violence (Levant et al. 2009; Martínez-Ferrer et al. 2018). Although this is one potential explanation, the downside is that it is a borderline explanation in the sense that poor family functioning is not necessarily related to violence. In the authors' opinion, these results are very interesting and they should therefore be explored further.

Secondly, and as regards family self-concept, it was observed that the effect of interaction with cybervictimization and gender followed the same trend as in the case of family functioning. The results showed that the boys presented higher scores than the girls when cybervictimization was high, but in situations of low cybervictimization, girls and boys had a high and similar family self-concept. This result is related to one extremely important fact, which appeared at the beginning of the last century with symbolic interactionists (Brown and Lohr 1987; Pons Diez 2010; Serpe and Stryker 2011; Shalin 2015), and it continues today with the theory of empowerment (Cattaneo and Goodman 2015; Musitu and Buelga 2004; Peterson 2014; Song 2012), namely that parenting styles and other dimensions of the family environment, such as family communication, are considered to be processes that have certain outcomes or resources, and one of the results of these processes is self-concept (Collins 2011). This study infers that these processes are weaker in the cases of adolescent cyber-bullying victims. To summarize, the fact that cyber-victimized adolescents presented a lower family self-concept is related to the idea that family socialization processes are intimately linked to family functioning, as are parenting styles when family functioning is negative, having a negative effect on the self-concept of adolescents. It is important to emphasize that self-concept has been identified as an important predictor of criminal behavior (Barry et al. 2007), violent behavior (Babore et al. 2017; Estévez et al. 2006), and substance use (Musitu et al. 2007).

Finally, and in relation to the academic self-concept, the results showed that, when cybervictimization was low and moderate, boys and girls showed significant differences, which were greater in the girls in both cases. When cybervictimization was high, boys and girls showed the lowest scores of the three groups, but it was the girls who presented the lowest levels. Our results revealed gender differences in academic self-concept, which is consistent with findings that were reported in previous studies (Jansen et al. 2014), and supports the idea that, when girls are victimized, their academic self-concept diminishes, a situation that does not occur in boys. Previous studies have described the relationship between academic self-concept and adjustment variables, such as anxiety, intrinsic motivation, and academic performance (Khalaila 2015). In turn, these variables have been observed to be significantly related to cyberbullying and cybervictimization (Litwiller and Brausch 2013). This result seems significant, especially since it was observed that poor family functioning not only influences this environment internally, but it also extends to another very important scenario in this period of adolescence, namely school. It is important to note that the results obtained in this study showed that boys and girls seem to differ in the way that they interpret complex situations with high emotional content. In this sense, other authors have reported that girls interpret emotions better (Levant et al. 2009), and have better emotional self-concept than boys (Ortega-Barón et al. 2016), which could explain its greater sensitivity and permeability in situations of cybervictimization. As regards academic self-concept, performance, and academic adjustment (Jansen et al. 2014; Khalaila 2015), it has also been observed that girls present higher levels and adjustment than boys in non-violent or peaceful situations. These results may be explained by gender schemes that are acquired through socialization processes and they result in the learning of 
behaviors that are considered to be socially appropriate for men and women (Santoro et al. 2018; Yubero Jimenez and Olivas 2010).

Finally, we believe that this study provides suggestive and relevant observations regarding certain variables that are involved in cybervictimization. However, it is important to note that the results obtained in this study must be interpreted with caution, due to its transversal and correlational nature, which, as is well known, does not allow causal relationships to be established between the variables. A longitudinal study with measurements at different times would help to clarify the relationships that were observed here.

Despite these limitations, the authors believe that this study provides interesting and valuable results regarding the relationship between cyberbullying and the emotional variables of psychological distress and, above all, suicidal ideation, as well as the fundamental role that is played by family as a protection context. These findings highlight the importance of the role of family and gender in the strengthening of resources, such as self-concept, which have a protective effect on the interaction of adolescents with their peers at school and on virtual social media.

Author Contributions: All the authors of the manuscript contributed equally to the research and writing of the present study.

Funding: This study was funded by the project "Bullying in adolescence: individual and family variables", and subsidised by Support Scientific and Technological Research Programme (PAYCIT) by the Autonomous University of Nuevo Leon (UNAL) (Mexico).

Conflicts of Interest: The authors declare no conflict of interest.

\section{References}

Ak, Şerife, Yalçin Özdemir, and Yaşar Kuzucu. 2015. Cybervictimization and Cyberbullying: The Mediating Role of Anger, Don't Anger Me! Computers in Human Behavior 49: 437-43. [CrossRef]

Antoniadou, Nafsika, and Constantinos M. Kokkinos. 2015. Cyber and School Bullying: Same or Different Phenomena? Aggression and Violent Behavior 25: 363-72. [CrossRef]

Aricak, Osman Tolga, and Ahmet Ozbay. 2016. Investigation of the Relationship between Cyberbullying, Cybervictimization, Alexithymia and Anger Expression Styles among Adolescents. Computers in Human Behavior 55: 278-85. [CrossRef]

Aymerich, María del Milagro, Gonzalo Musitu, and Francisco Palmero. 2018. Family Socialisation Styles and Hostility in the Adolescent Population. Sustainability 10: 2962. [CrossRef]

Babore, Alessandra, Leonardo Carlucci, Fedele Cataldi, Vicky Phares, and Carmen Trumello. 2017. Aggressive Behaviour in Adolescence: Links with Self-Esteem and Parental Emotional Availability. Social Development 26: 704-42. [CrossRef]

Barry, Christopher T., Sarah J. Grafeman, Kristy K. Adler, and Jessica D. Pickard. 2007. The Relations among Narcissism, Self-Esteem, and Delinquency in a Sample of at-Risk Adolescents. Journal of Adolescence. [CrossRef]

Brewer, Gayle, and Jade Kerslake. 2015. Cyberbullying, Self-Esteem, Empathy and Loneliness. Computers in Human Behavior 48: 255-60. [CrossRef]

Brighi, Antonella, Annalisa Guarini, Giannino Melotti, Silvia Galli, and Maria Luisa Genta. 2012. Predictors of Victimisation across Direct Bullying, Indirect Bullying and Cyberbullying. Emotional and Behavioural Difficulties 17: 375-88. [CrossRef]

Brown, B. Bradford, and Mary Jane Lohr. 1987. Peer-Group Affiliation and Adolescent Self-Esteem: An Integration of Ego-Identity and Symbolic-Interaction Theories. Journal of Personality and Social Psychology 52: 47-55. [CrossRef] [PubMed]

Buelga, Sofía, and Gonzalo Musitu. 2006. Famille et Adolescence: Prévention de Conduites à Risque [Family and Adolescence: Preventions of Risk Behaviour]. In Adolescences d'aujourd'hui. Edited by Denis Jacquet and Marc Zabalia. Rennes: PUF, pp. 17-35.

Buelga, Sofía, María Jesús Cava, and Gonzalo Musitu. 2010. Cyberbullying: Victimizacion Entre Adolescentes a Través Del Teléfono Movil y de Internet [Cyberbullying: Victimization among Adolescents through Mobile Phone and Internet]. Psicothema 22: 784-89. [CrossRef] [PubMed] 
Buelga, Sofía, María Jesús Cava, and Gonzalo Musitu. 2012. Validation of the Adolescent Victimization through Mobile Phone and Internet Scale. Revista Panamericana de Salud Pública = Pan American Journal of Public Health 32: 36-42. [CrossRef] [PubMed]

Buelga, Sofía, Belén Martínez-Ferrer, and Gonzalo Musitu. 2016. Family Relationships and Cyberbullying. In Cyberbullying Across the Globe: Gender, Family, and Mental Health. Edited by Raúl Navarro, Santiago Yubero and Elisa Larrañaga. España: Springer, pp. 99-114. [CrossRef]

Buelga, Sofía, Belén Martínez-Ferrer, and María Jesús Cava. 2017. Differences in Family Climate and Family Communication among Cyberbullies, Cybervictims, and Cyber Bully-victims in Adolescents. Computers in Human Behavior 76: 164-73. [CrossRef]

Calvete, Esther, Izaskun Orue, and Manuel Gámez-Guadix. 2016. Cyberbullying Victimization and Depression in Adolescents: The Mediating Role of Body Image and Cognitive Schemas in a One-Year Prospective Study. European Journal on Criminal Policy and Research. [CrossRef]

Castilla, Humberto A., Tomas P. Caycho, Midori Shimabukuro, and Amalia A. Valdivia. 2014. Percepción Del Funcionamiento Familiar: Análisis Psicométrico de La Escala APGAR-Familiar En Adolescentes de Lima [Perception of Family Functioning: Psychometric Analysis of the APGAR-Family Scale in Adolescents in Lima]. Propósitos y Representaciones 2: 49-58. [CrossRef]

Cattaneo, Lauren Bennett, and Lisa A. Goodman. 2015. What Is Empowerment Anyway? A Model for Domestic Violence Practice, Research, and Evaluation. Psychology of Violence 5: 84-94. [CrossRef]

Cava, María Jesús, Sergio Murgui, and Gonzalo Musitu. 2008. Diferencias En Factores de Protección Del Consumo de Sustancias En La Adolescencia Temprana y Media [Differences in Protective Factors for Substance Use in Early and Middle Adolescence]. Psicothema 20: 389-95. [PubMed]

Chan, Heng Choon Oliver, and Dennis S.W. Wong. 2015. Traditional school bullying and cyberbullying in Chinese societies: Prevalence and a review of the whole-school intervention approach. Aggression and Violent Behavior 23: 98-108. [CrossRef]

Chou, Hui Lien, Chien Chou, and Chao Hsiu Chen. 2016. The Moderating Effects of Parenting Styles on the Relation between the Internet Attitudes and Internet Behaviors of High-School Students in Taiwan. Computers and Education 94: 204-14. [CrossRef]

Closas, Antonio Humberto, Edgardo Alberto Arriola, Cristina Isabel Kuc, Rosana Amarilla, and Ethel Carina Jovanovich. 2013. Análisis Multivariante, Conceptos y Aplicaciones En Psicología Educativa y Psicometría [Multivariate Analysis, Concepts and Applications in Educational Psychology and Psychometry]. Enfoques XXV: 65-92.

Collins, Randall. 2011. Wiley's Contribution to Symbolic Interactionist Theory. American Sociologist 42: 156-67. [CrossRef]

Cuesta, Marcelino, Eduardo Fonseca-Pedrero, Guillermo Vallejo, and José Muñiz. 2013. Datos Perdidos y Propiedades Psicométricas En Los Tests de Personalidad [Lost Data and Psychometric Properties in Personality Test]. Anales de Psicologia 29: 285-92. [CrossRef]

De Santisteban, Patricia, and Manuel Gámez-Guadix. 2017. Estrategias de persuasión en grooming online de menores: Un análisis cualitativo con agresores en prisión [Persuasion strategies in online grooming of young people: A qualitative analysis with aggressors in prison]. Psychosocial Intervention 26: 139-46. [CrossRef]

Durán-Segura, Mercedes, and Roberto Martínez-Pecino. 2015. Ciberacoso Mediante Teléfono Móvil e Internet En Las Relaciones de Noviazgo Entre Jóvenes [Cyberbullying Trough Mobile Phone and the Internet in Dating Relationships on Youth]. Comunicar. Revista Científica de Comunicación y Educación 22: 159. [CrossRef]

Elsaesser, Caitlin, Beth Russell, Christine McCauley Ohannessian, and Desmond Patton. 2017. Parenting in a Digital Age: A Review of Parents' Role in Preventing Adolescent Cyberbullying. Aggression and Violent Behavior. [CrossRef]

Estévez, Estefanía, Belén Martínez, and Gonzalo Musitu. 2006. La Autoestima En Adolescentes Agresores y Víctimas En La Escuela: La Perspectiva Multidimensional [Self-Esteem in Adolescent Aggressors and Victims in School: The Multidimensional Perspective]. Psychosocial Intervention 15: 223-32.

Estévez, Estefanía, Teresa I. Jiménez, and María Jesús Cava. 2016. A Cross-Cultural Study in Spain and Mexico on School Aggression in Adolescence: Examining the Role of Individual, Family, and School Variables. Cross-Cultural Research 50: 123-53. [CrossRef] 
Extremera, Natalio, Cirenia Quintana-Orts, Sergio Mérida-López, and Lourdes Rey. 2018. Cyberbullying Victimization, Self-Esteem and Suicidal Ideation in Adolescence: Does Emotional Intelligence Play a Buffering Role? Frontiers in Psychology 9: 367. [CrossRef] [PubMed]

Fanti, Kostas A., Andreas G. Demetriou, and Veronica V. Hawa. 2012. A Longitudinal Study of Cyberbullying: Examining Risk and Protective Factors. European Journal of Developmental Psychology 9: 168-81. [CrossRef]

Fuentes, María C., José Fernando García, Enrique Gracia, and Marisol Lila. 2011. Autoconcepto y Ajuste Psicosocial En La Adolescencia [Self-Concept and Psychosocial Adjustment in Adolescence]. Psicothema 23: 7-12. [PubMed]

Fuentes, Maria C., Fernando García, Enrique Gracia, and Antonio Alarcon. 2015. Parental Socialization Styles and Psychological Adjustment. A Study in Spanish Adolescents. Revista de Psicodidáctica 27: 1-32. [CrossRef]

Garaigordobil, Maite. 2017. Conducta Antisocial: Conexión Con Bullying/Cyberbullying y Estrategias de Resolución de Conflictos [Antisocial Behaviour: Connection to Bullying/Cyberbullying and Conflict Resolution Strategies]. Psychosocial Intervention 26: 47-54. [CrossRef]

Garaigordobil, Maite, and Ainhoa Durá. 2006. Relaciones Del Autoconcepto y La Autoestima Con La Sociabilidad, Estabilidad Emocional y Responsabilidad En Adolescentes de 14 a 17 Años [Relationships of Self-Concept and Self-Esteem with Sociability, Emotional Stability and Responsibility in Adolescent]. Análisis y Modificación de Conducta 32: 37-64.

García, Fernando, and Gonzalo Musitu. 1999. AF5: Autoconcepto Forma 5 [SF5: Self-Concept Form 5]. Madrid: TEA Ediciones.

Gentile, Brittany, Shelly Grabe, Brenda Dolan-Pascoe, Jean M. Twenge, Brooke E. Wells, and Alissa Maitino. 2009. Gender Differences in Domain-Specific Self-Esteem: A Meta-Analysis. Review of General Psychology 13: 34-45. [CrossRef]

Giménez Gualdo, Ana M., Simon C. Hunter, Kevin Durkin, Pilar Arnaiz, and Javier J. Maquilón. 2015. The Emotional Impact of Cyberbullying: Differences in Perceptions and Experiences as a Function of Role. Computers E Education 82: 228-35. [CrossRef]

Hair, Joseph F., Rolph E. Anderson, Ronald L. Tatham, and William C. Black. 1999. Análisis Multivariante [Multivariate Analysis], 4th ed. España: Prentice Hall.

Hinduja, Sameer, and Justin W. Patchin. 2012. Cyberbullying: Neither an Epidemic nor a Rarity. European Journal of Developmental Psychology 9: 539-43. [CrossRef]

Hosseinmardi, Homa, Sabrina Arredondo Mattson, Rahat Ibn Rafiq, Richard Han, Qin Lv, and Shivakant Mishra. 2015. Analyzing Labeled Cyberbullying Incidents on the Instagram Social Network. In Lecture Notes in Computer Science (Including Subseries Lecture Notes in Artificial Intelligence and Lecture Notes in Bioinformatics). Cham: Springer, vol. 9471, pp. 49-66. [CrossRef]

Huang, Xiuqin, Huimin Zhang, Mengchen Li, Jinan Wang, Ying Zhang, and Ran Tao. 2010. Mental Health, Personality, and Parental Rearing Styles of Adolescents with Internet Addiction Disorder. Cyberpsychology, Behavior, and Social Networking 13: 401-6. [CrossRef]

Jansen, Malte, Ulrich Schroeders, and Oliver Lüdtke. 2014. Academic Self-Concept in Science: Multidimensionality, Relations to Achievement Measures, and Gender Differences. Learning and Individual Differences 30: 11-21. [CrossRef]

Katzer, Catarina, Detlef Fetchenhauer, and Frank Belschak. 2009. Cyberbullying: Who Are the Victims? A Comparison of Victimization in Internet Chatrooms and Victimization in School. Journal of Media Psychology 21: 25-36. [CrossRef]

Khalaila, Rabia. 2015. The Relationship between Academic Self-Concept, Intrinsic Motivation, Test Anxiety, and Academic Achievement among Nursing Students: Mediating and Moderating Effects. Nurse Education Today 35: 432-38. [CrossRef] [PubMed]

Kowalski, Robin M., and Susan P. Limber. 2013. Psychological, Physical, and Academic Correlates of Cyberbullying and Traditional Bullying. Journal of Adolescent Health 53: 20. [CrossRef] [PubMed]

Kowalski, Robin M., Gary W. Giumetti, Amber N. Schroeder, and Micah R. Lattanner. 2014. Bullying in the Digital Age: A Critical Review and Meta-Analysis of Cyberbullying Research among Youth. Psychological Bulletin 140: 1073. [CrossRef] [PubMed]

Kowalski, Robin M., Susan P. Limber, and Annie McCord. 2018. A Developmental Approach to Cyberbullying: Prevalence and Protective Factors. Aggression and Violent Behavior. [CrossRef] 
Levant, Ronald F., Rosalie J. Hall, Christine M. Williams, and Nadia T. Hasan. 2009. Gender Differences in Alexithymia. Psychology of Men and Masculinity 10: 190. [CrossRef]

Litwiller, Brett J., and Amy M. Brausch. 2013. Cyber Bullying and Physical Bullying in Adolescent Suicide: The Role of Violent Behavior and Substance Use. Journal of Youth and Adolescence 42: 675-84. [CrossRef] [PubMed]

Livingstone, Sonia, Leslie Haddon, and Anke Görzig. 2011. Risks and Safety on the Internet: The Perspective of European Children: Full Findings and Policy Implications from the EU Kids Online Survey of 9-16 Year Olds and Their Parents in 25 Countries. EU Kids Online Network. London: LSE.

Martínez-Ferrer, Belén, Estefanía Estévez-López, and Teresa I Jiménez-Gutiérrez. 2003. Influencia Del Funcionamiento Familiar En La Conducta Disruptiva En Adolescentes [The Influence of Familily System in Adolescents' Disruptive Behaviour]. Encuentros En Psicología Social 1: 64-67.

Martínez Ferrer, Belén, David Moreno Ruiz, Luis Vicente Amador, and Jim Oxford. 2011. Victimización Escolar En Adolescentes. Un Análisis Desde La Perspectiva Ecológica [School Victimization Among Adolescents. An Analysis from an Ecological Perspective]. Psychosocial Intervention 20: 149-60. [CrossRef]

Martínez-Ferrer, Belén, David Moreno, and Gonzalo Musitu. 2018. Are Adolescents Engaged in the Problematic Use of Social Networking Sites More Involved in Peer Aggression and Victimization? Frontiers in Psychology. [CrossRef]

Martins, Maria José D., Ana Margarida Veiga Simão, Isabel Freire, Ana Paula Caetano, and Armanda Matos. 2016. Cyber-Victimization and Cyber- Aggression among Portuguese Adolescents: The Relation to Family Support and Family Rules. International Journal of Cyber Behavior, Psychology and Learning 6: 65-68. [CrossRef]

Moral Jiménez, María de la Villa, and Anastasio Ovejero Bernal. 2013. Percepción Del Clima Social Familiar y Actitudes Ante El Acoso Escolar En Adolescentes [Perception of Family Social Climate and Attitudes to Bullying in Adolescents]. European Journal of Investigation in Health, Psychology and Education 3: 149-60. [CrossRef]

Moreno, David, Estefanía Estévez, Sergio Murgui, and Gonzalo Musitu. 2009. Reputación Social y Violencia Relacional En Adolescentes: El Rol de La Soledad, La Autoestima y La Satisfacción Vital [Social Reputation and Relational Aggression in Adolescence. The Role of Loneliness, Self-Esteem and Life Satisfaction]. Psicothema 21: 537-42.

Musitu, Gonzalo, and Sofía Buelga. 2004. Desarrollo Comunitario y Potenciación (Empowerment) [Community Development and Empowerment]. In Introducción a La Psicologia Comunitaria. Edited by G. Musitu Ochoa, J. Herrero Olaizola, Leonor M. Cantera and Marisela Montenegro Martínez. Barcelona: UOC, pp. 167-95.

Musitu, Gonzalo, Teresa I. Jiménez, and Sergio Murgui. 2007. Funcionamiento Familiar, Autoestima y Consumo de Sustancias En Adolescentes: Un Modelo de Mediación [Family Functioning, Self-Esteem and Substance Use in Adolescents: A Model of Mediation]. Salud Publica de Mexico 49: 3-10. [CrossRef] [PubMed]

Navarro, Raúl, Santiago Yubero, and Elisa Larrañaga. 2015. Psychosocial Risk Factors for Involvement in Bullying Behaviors: Empirical Comparison Between Cyberbullying and Social Bullying Victims and Bullies. School Mental Health. [CrossRef]

Ortega-Barón, Jessica, Sofía Buelga, and María-Jesús Cava. 2016. The Influence of School Climate and Family Climate among Adolescents Victims of Cyberbullying. Comunicar 46: 57-65. [CrossRef]

Özdemir, Yalçin. 2014. Cyber Victimization and Adolescent Self-Esteem: The Role of Communication with Parents. Asian Journal of Social Psychology 17: 255-63. [CrossRef]

Peterson, N. Andrew. 2014. Empowerment Theory: Clarifying the Nature of Higher-Order Multidimensional Constructs. American Journal of Community Psychology 53: 96-108. [CrossRef] [PubMed]

Pons Diez, Xavier. 2010. La Aportación a La Psicología Social Del Interaccionismo Simbólico: Una Revisión Histórica [The Contribution of Symbolic Interactionism to Social Psychology: A Historical Review]. EduPsykhé 9: 23-41.

Santoro, Chiara, Belén Martínez-Ferrer, Carmen Monreal Gimeno, and Gonzalo Musitu. 2018. New Directions for Preventing Dating Violence in Adolescence: The Study of Gender Models. Frontiers in Psychology. [CrossRef]

Sasson, Hagit, Gustavo Mesch, Donna Cross, Amy Barnes, Alana Papageorgiou, Kate Hadwen, Lydia Hearn, and Leanne Lester. 2015. A Social-Ecological Framework for Understanding and Reducing Cyberbullying Behaviours. Aggression and Violent Behavior 23: 109-17. [CrossRef]

Serpe, Richard T., and Sheldon Stryker. 2011. The Symbolic Interactionist Perspective and Identity Theory. In Handbook of Identity Theory and Research. New York: Springer, pp. 225-48. [CrossRef] 
Shalin, Dmitri N. 2015. Making the Sociological Canon: The Battle over George Herbert Mead's Legacy. The American Sociologist 46: 313-40. [CrossRef]

Shavelson, Richard J., Judith J. Hubner, and George C. Stanton. 1976. Self-Concept: Validation of Construct Interpretations. Review of Educational Research 46: 407-41. [CrossRef]

Smilkstein, Gabriel, Clark Ashworth, and Dan Montano. 1982. Validity and Reliability of the Family APGAR as a Test of Family Function. The Journal of Family Practice 15: 303-11. [PubMed]

Song, Liyu. 2012. Service Utilization, Perceived Changes of Self, and Life Satisfaction Among Women Who Experienced Intimate Partner Abuse: The Mediation Effect of Empowerment. Journal of Interpersonal Violence 27: 1112-36. [CrossRef] [PubMed]

Stoll, Laurie Cooper, and Ray Block. 2015. Intersectionality and Cyberbullying: A Study of Cybervictimization in a Midwestern High School. Computers in Human Behavior 52: 387-97. [CrossRef]

Tokunaga, Robert S. 2010. Following You Home from School: A Critical Review and Synthesis of Research on Cyberbullying Victimization. Computers in Human Behavior 26: 277-87. [CrossRef]

Wachs, Sebastian, Gabriela Ksinan Jiskrova, Alexander T. Vazsonyi, Karsten D. Wolf, and Marianne Junger. 2016. A Cross-National Study of Direct and Indirect Effects of Cyberbullying on Cybergrooming Victimization via Self-Esteem. Psicología Educativa 22: 61-70. [CrossRef]

Watts, Lynette K., Jessyca Wagner, Benito Velasquez, and Phyllis I. Behrens. 2017. Cyberbullying in Higher Education: A Literature Review. Computers in Human Behavior. [CrossRef]

World Medical Association. 2013. Declaration of Helsinki World Medical Association Declaration of Helsinki Ethical Principles for Medical Research Involving Human Subjects. The Journal of the American Medical Association. [CrossRef]

Yubero Jimenez, Santiago, and Raúl Navarro Olivas. 2010. Socialización de Género [Gender Socialization]. In Intervención Social y Género. Madrid: Narcea, pp. 43-72.

(C) 2019 by the authors. Licensee MDPI, Basel, Switzerland. This article is an open access article distributed under the terms and conditions of the Creative Commons Attribution (CC BY) license (http:/ / creativecommons.org/licenses/by/4.0/). 